\title{
Taxonomic Results of the BRYOTROP Expedition to Zaire and Rwanda 33. Splachnaceae, Tayloria
}

\author{
M. Boecker
}

Botanisches Institut der Universität Bonn, Meckenheimer Allee 170, D-53115 Germany

A revision of the african species of the genus has been published by Koponen \& Weber (1972). Out of eight African species named by O’Shea (1995) two quite common ones have been found on the BRYOTROP III Expedition.

Abbreviations: $\mathrm{KB}=$ Kahuzi-Biega National Park, Zaire, Ny = Nyungwe Forest, Rwanda, Ka $=$ Mt. Karisimbi, Rwanda. For the descriptions of the collecting sites see Fischer (1993).

Tayloria kilimandscharica Broth.

T. kilimandscharica has been recorded from central eastern Africa, that is Zaire, Rwanda, Uganda, Tanzania and Kenia (O’Shea 1995). Remarks on occurence in Zaire, Rwanda and Uganda and on characteristics of this species see De Sloover (1973).

On the BRYOTROP III Expedition all $T$. kilimandscharica have been found within the alpine belt of Mt. Karisimbi, Rwanda, between 3600 and 4280m in Senecio refractisquamatus Lobelia wollastonii - Paramo or in Alchemilla johnstonii - vegetation. All samples were collected from Senecio -Stems.
Ka: 162, J.-P. Frahm 8050; 163, J.-P. Frahm 8056, T. Pócs 8067, 8184; 164, T. Pócs 8113.

Tayloria orthodonta (P. Beauv.) Wijk \& Marg. $T$. orthodonta is known from a wide range of subSaharan Africa from west to southeast, that will mean from Guinea, Sierra Leone, Cameroon, Zaire, Rwanda, Ethiopia, Kenya, Tanzania, Malawi, Zimbabwe, the former Transvaal, Madagascar and Reunion (O'Shea 1995). Remarks on occurence in Zaire and Rwanda and on characteristics of this species see De Sloover (1973).

On the BRYOTROP III Expedition it could be found in Rwanda near Cyangugu / Foret de Nyungwe in a mesic montane evergreen forest $(2300 \mathrm{~m})$ at the bank of a trail and in the zone of transition to submontane rainforest $(2000 \mathrm{~m})$, growing on bark.

In Zaire it has been encountered in a bamboo stand on Mt. Biega at $2500 \mathrm{~m}$, growing on bamboo (Arundinaria alpina).

Ny: 110, T. Pócs 6495; 111, J.-P. Frahm 6420; KB: $136, T$. Pócs 7249. 


\section{References}

De Sloover, J.L. 1973. Note de bryologie africaine I. Brachydontium, Atractylocarpus, Amphidium, Rhabdoweisia, Tayloria, Rhacocarpus, Trachypodopsis. Bull. Jard. Bot. Nat. Belg. / Bull. Nat. Plantentuin Belg. 43: 333-348.

Fischer, E. 1993. Taxonomic results of the BRYOTROP Expedition to Zaire and Rwanda 3. Description of collecting sites. Trop. Bryol. 8: 13-38.

Koponen, T. \& Weber, W.A. 1972. A revision of African Tayloriae (Splachnaceae), including Bryomnium. Ann. Bot. Fennici 9: 126-134.

O'Shea, B.J. 1995. Checklist of the mosses of subSaharan Africa. Tropical Bryology 10: 91-198. 